\title{
Finnish Eyes on Border Schools : Teacher Educators Compare Notes
}

\author{
Kralovec, Etta
}

2017

Kralovec , E , Dervin , F \& Riitaoja , A-L 2017 , ' Finnish Eyes on Border Schools : Teacher

Educators Compare Notes ' , Schools: Studies in Education , vol. 14 , no. 1 , pp. 8-27 . https://doi.org/10.1086/69124

http://hdl.handle.net/10138/233862

https://doi.org/10.1086/691249

acceptedVersion

Downloaded from Helda, University of Helsinki institutional repository.

This is an electronic reprint of the original article.

This reprint may differ from the original in pagination and typographic detail.

Please cite the original version. 
Finnish Eyes on Border Schools: Teacher Educators Compare Notes

This is an Accepted Manuscript of an article published by the university of Chicago Press in Schools: Studies in Education, available online: http://www.tandfonline.com/10.1080/14708477.2013.866125

Reference: Etta Kralovec, Fred Dervin, and Anna-Leena Riitaoja, "Finnish Eyes on Border Schools: Teacher Educators Compare Notes," Schools 14, no. 1 (Spring 2017): 8-27. https://doi.org/10.1086/691249 


\title{
Finnish Eyes on Border Schools: Teacher Educators Compare Notes
}

\author{
Kralovec, Etta; Dervin, Fred \& Riitaoja, Anna-Leena
}

Whan that Aprill with his shoures soote The droghte of March hath perced to the roote, And bathed every veyne in swich licour Of which vertu engendred is the flour... Thanne longen folk to goon on pilgrimages. . .

\section{Prologue}

Chaucer, Caunterbury Tales

My sabbatical trip to Finland seemed, from the beginning, more of a pilgrimage than a field research trip. Finland has captured the imagination of educators from around the world with its meteoric rise to stardom in the world of education. With the highest test scores in the world, educators from around the world want to know Finland's 'secret sauce.'

Educational trips to Finland have become a cottage industry. Some of these trips charge close to 500 dollars a day for visiting Finnish schools. Finland is exporting schools to the Middle East as well as building classrooms in China that use the wildly popular Angry Birds game as a basis to fulfil the 'fun learning' ideology that Finland is famous for. Morgan Spurlock featured Finnish schools in a segment of his show "Inside Man.” Just google 'Finnish miracle' and you get over 580,000 results. Pasi Sahlberg, the loudest voice in the Finnish miracle story, regales American audiences with stories of the beauty of Finnish education: well-educated teachers, trust in teachers and no outside accountability. Sahlberg told an audience at the Teachers College of Columbia University: “There's no word for accountability in Finnish; accountability is something that is left when responsibility has been subtracted" (Partanen 2011).

For me, as a teacher educator, I wondered how teachers were prepared in Finland. The academic literature coming out of Finland on teacher education all inspired me to 
want to see how indeed they achieved the miracle of education that they discussed (Niemi et al. 2012; Hökkä and Eteläpelto 2014; Maaranen et al. 2008; Husu 2003). It seemed here was a place that took very seriously the need to re-design the teacher education system and in some cases it seemed they had achieved that (Sahlberg 2014). Contacting the Finnish scholars whose work I admired, I arranged to conduct field work in two of Finland's 8 teacher training schools, the Viikki Training School associated with the University of Helsinki and the teacher training school at the University of Jyväskylä. I spent two weeks at each school, engaging in classes, talking to student teachers and mentor teachers, and sitting in on their meetings.

I went looking for miracles but instead found hardworking teachers, mentoring new teachers with skill and grace. It seemed pretty obvious that the 15-minute recess every 45 minutes did wonders to focus student attention in the classroom. Pans of freshly cooked vegetables, meat, fish, fresh fruit and yogurt, helped students prepare for their afternoon classes. Student teachers worked in pairs, fostering their ability to collaborate and reflect when they became teachers. Teachers taught four out of their 8-hour workday; the other four hours were spent working with new teachers, designing curriculum, and developing programs.

When I met with the Education for Diversity (E4D) research group at the University of Helsinki, I gained a critical perspective of the schools I had been conducting research in. The head of the E4D research group, Professor Fred Dervin, said with a glint in his eye, "You have been to Disneyland my dear, not all our schools are that lovely." Over the course of conversations with members of this research group, I invited Fred and his colleague 
Anna-Leena to visit our schools on the Arizona/Mexico border, where I work with highpoverty schools, some of which are over $95 \%$ Hispanic. Additionally, in some of these schools, there are many students from Mexico crossing the border each day to attend these schools. My university teacher education program has been preparing teachers for these border schools for over 10 years. While I was in Finland, I presented our initial research findings on this work. Fred and Anna-Leena found the research situation so compelling that we planned an opportunity for them to conduct field research in our partner schools.

At the end of their time with us, we agreed to record a conversation about their impressions of our border schools. What follows is an edited transcription and analysis of that conversation where we see border schools through Finnish eyes and compare differences and similarities.

\section{The Educators' Tales:}

Drs. Dervin and Riitaoja seemed perfectly suited to study border schools.

Fred Dervin is Professor of Multicultural Education at the University of Helsinki and also holds several professorships in Australia, Canada, Luxembourg and Malaysia. He was recently appointed Chair Professor of Education at Renmin University in China. Professor Dervin specializes in intercultural education, the sociology of multiculturalism and student and academic mobility. Fred has widely published in international journals on identity, the 'intercultural,' and mobility/migration. He has published over 40 books and is the editor of international journals and book series on intercultural communication education. 
His colleague Anna-Leena Riitaoja, works as a senior lectures at the Faculty of Educational Sciences, University of Helsinki, Finland. Her research interests are related to sociology and philosophy of education, epistemologies of social and educational research and intersectional structures of equality and inequality, using the analytic tools from postcolonial, post-structural feminist studies and critical whiteness studies. She has published on multiculturality and interculturality in education, methodological nationalism and colonialism in multicultural education. She is particularly interested in the 'othering' of immigrant students in Finland.

In the winter of 2016, Dervin and Riitaoja began a two-week research trip in the Arizona borderlands, tagging along as we observed student teachers, meeting with principals whose students cross the border each day to attend school in the U.S., and trying to find common ground and dissonance between our two systems. I have been working for the past ten years with these schools, preparing new teachers for the enormous challenges of teaching in border schools. Our teacher preparation program works closely with our school partners to prepare teachers with commitments to equity literacy, inquiry and classroom empowerment rather than management. The program builds on lessons learned from the Mexican American Studies (MAS) program in Tucson, Arizona, a program outlawed in 2010 by the Arizona State Legislature. According to Curtis Acosta, a Mexican American studies teacher, "The MAS program was a way to engage those students who found school rote and unexciting, or those who might otherwise drop out. In fact, a year later, the University of Arizona would publish a 
report that found offering Mexican American studies increased graduation rates, grades, and college enrollment”. (Phippen 2015).

We made extensive visits to three high-poverty high schools in the Arizona borderlands. We visited a high school in Douglas, Arizona, a town of 16,000, with a median household income of $\$ 26,222,77 \%$ Hispanic, which shares the border with Aqua Prieta, Sonora, Mexico. The high school is $98 \%$ Hispanic. One high school was four miles from the border in Bisbee, an old mining town of 6,000, with a median household income of $\$ 33,722$. Bisbee is $40 \%$ Hispanic, but the high school is $70 \%$ Hispanic students. We also visited a large city high school in Tucson, 90 miles from the border with population of half a million, of whom $43 \%$ are Hispanic. Tucson has a median household income of $\$ 35,000$. The high school we visited in Tucson is $90 \%$ Hispanic. In comparison, the Arizona median income is $\$ 50,068$.

Over those two weeks, there were themes that we returned to over and over as our Finnish guests tried to make sense of US schooling, border style. At the end of the two weeks, we decided to record our final conversation, which turned into a 2-day roving conversation that moved from LGBTQ acceptance in border schools to questions of whether education is possible without indoctrination. Let's listen in to this edited version of the conversation.

Etta Kralovec (ET): Over the course of the last two weeks we have explored the ways in which US and Finnish schools differ and the ways in which they are similar. I have been really struck by your ability to focus on parts of schooling here that to me are invisible. We 
live in these school environments and we don't question the 'invisibles' of that environment, in part, because we don't really see them. There were some comments that both of you made in our school visits that I'd like to return to. One of those things was about the omnipresence of the flag and what it represents. Another thing was the IQ testing, which surprised both of you enormously. And finally, the presence of LGBTQ clubs in the school also surprised you, so let's start with the things that surprised you.

Fred Dervin (FD): Let's start with the American flag. Very surprising in the sense that it's all over the place in every school and we were told by a principal that there is a law saying that there should be a flag in every single classroom.

Personally I've always been very anti-flag in a sense because the flag to me and probably Anna-Leena as well, has a very special meaning. It's the extreme. It's chauvinism. In Finland the flag was created in 1917, but in other countries it is from the $18^{\text {th }}$ century and the flags were actually signs of repression at the beginning. Like when the French Republic was created, that was a way of trying to tell people from very different regions and languages that they'd been forced to speak French and to become French, people had to adopt a 'French identity.' These days, because of the migrant situation at the moment in Europe, the flag is coming back into fashion for certain people who believe in the superiority and uniqueness of their country and 'culture'. Karl Klaus $(1990,121)$ summarizes well what I am trying to say: "the unattractive thing about chauvinism is not so much the aversion of other nations, but the love of one's own."

When I was in Paris some weeks ago, I was so shocked that there were French flags all over the place, like a sea of flags, which you wouldn't see before because the French 
flag was very much related to the National Front. Finland is moving in that direction as well. So seeing all these flags all over here and people having to stand up in the morning and put their hands on their hearts is a bit scary. I mean apparently they don't have to do it in all the schools, they can just stand up and can be silent, but still. We had this discussion with one of the principals about the meaning of the word patriotic. Patriotism to us is negative because it means that behind patriotism there's always, implicitly, the idea that you are better than others. I don't believe that you can be patriotic and proud of your country, culture or identity without implicitly or subconsciously thinking that what your nation is about is better. And they said, "No, no that's not the meaning here. You mean Nationalism." I was not very convinced of the difference between patriotism and nationalism.

Anna-Leena Riitaoja (ALR): I think that people hope to make a difference between "good" and "bad" types of nationalism, or between patriotism and nationalism as they call them here. However, if you look at what was the meaning of the flag in the very beginning, as Fred said, in France it was a symbol of oppression. Moreover, both nationalism and patriotism are related to the idea of the nation state. I think it's impossible to take the idea of the nationalism out of patriotism. Putting the flag on the wall and using the flag in different situations is a form of "banal nationalism" (Billig 1995). Billing wants us to understand critically the ways in which everyday representations of the nation, like the flag, attempt to build a sense of belonging among citizens; but which subliminally and symbolically maintains oppressive structures by 
focusing citizen attention on the symbol rather existing conditions of oppression that the flag salute obscures.

I also think the state is always oppressing towards some groups of people. Those who belong to the hegemonic group and who benefit from oppression can claim that "we all are the same and 'the nation state keeps the common good"' (Cavanagh 2004). But the nation state is always problematic those who don't belong to this hegemonic group. So there are divisions and hierarchies made both between citizens (e.g. Somers and Olin 2008) and between citizens and non-citizens (Kowalczyk and Popkewitz 2005; López López 2006).

FD: Especially in the schools we visited, I mean there are so many people who are half something. When I spoke to two Hispanic girls from one of the high schools we visited I asked them about this, "How do you feel about the flag?" And they said, "Well, it's part of us and we don't really have to say anything in the morning, we can just stand there."

But something that really shocked me was when I asked one of the principals what the undocumented kids in the school think about standing up and saluting that flag. She said these students were very proud because America is giving them freedom and education for free. How do you feel about this, do you think it is true?

EK: I think the principal has an uncritical acceptance of the status quo. I know that her son is in the military, so there is a level of patriotism that comes with military service. But I think saluting the flag is a problem for more than students who aren't citizens. I think it's 
a problem for all kids in school because for many, many students, it's a meaningless exercise. I think one of the things that happens when you do a meaningless exercise for years in school, students can become really cynical about the meaning of that exercise. Especially along the border, many of these kids are bi-national students, they talk openly about going to college in Mexico or to technical schools or just going to live in Mexico. So to them, pledging allegiance to one country doesn't mean the same thing that it means to administrators or state legislators or Governors, who think that they can create citizens through hollow patriotic activities.

ALR: I was thinking about the discussion yesterday when a student said that he didn't cross the border, the border crossed him. So if you think about that situation, that first the border has crossed you and then you are expected to pledge your allegiance to that flag, which represents a country that you were forced into. That's very strange.

EK: Many Anglo kids who have grown up here have no understanding of the history of the border. I've had students in graduate school who didn't know that where we are sitting used to belong to Mexico, and they were surprised by that. There's parts of every country's history that doesn't get told. And the history of the U.S./Mexico border is a piece of history that doesn't really get told, at least in the borderlands of Arizona.

FD: It's the same in Finland when you think of the Russian border. Some Finns say 'they stole part of our land.' And every year you have a huge meeting of people whose family 
was on that land when it was given back to Russia and they are asking for Karelia to be given back also. But if you know a bit of Finnish history, Finland at one point occupied Rukajärvi (Ругозеро, Rugozero) in Russia during the War of 1941-1944, with the help of Nazi Germany. People are not aware of that. Many didn't understand that it was about Finland doing a land grab; they thought it was about Finland fighting against Russia trying to grab our land. It was interesting because it shows the level of ignorance in a sense, but also the way such narratives are manipulated politically.

EK: So I guess we share some disconnects about history and the placement of historical borders. Whose history is told in US classrooms is a really big debate in this country. I did notice you both looking at the history textbooks and remarking at the lack of Spanish in the texts. But I would like us to talk about another issue that really surprised both of you, and that was our encounter with a special education needs teacher in one of the schools.

ALR: It was very surprising to us when the special needs teacher said they were testing IQ. In Europe, anything like that is very much related to race theory as it was articulated during the Second World War. In Finland generally, there haven't been people who are talking about IQ these days. There are however, in Finland, far out people who are open to Nazi ideology and racist thinking and who think that there are IQ differences between different groups of people, but it's not part of the general thinking. So the teacher in school saying that they test IQ is very shocking. If they think about a set IQ score, then educators think the student cannot move beyond that. This is very much a deficit approach to 
education and parents and their child must know this means they're going to have a challenge making it through school.

FD: What shocks me the most about it, especially when talking to this special needs teacher, was that first of all, there was no criticality on her part of what the meaning might be of what she was doing. And second of all, when I questioned the validity and the cultural bias of the test, she said, "No, no it's fine, it's been tested on different cultures and different people so it is working." But we know it's not working because it is biased (see Holliday 2010). The fact that she was using this as a tool, as a 'neutral' tool to try to help the students, that's extremely dangerous. She seemed to have a very static view on the IQ even though we know a lot more now about neuro-cognition that challenges the underlying assumptions of an IQ test.

EK: I am not sure that the test she was talking about was a real IQ test, it was probably one of the hundreds of tests they might give to students. When I asked the principal about this, she said, well she didn't know what the teacher was referring to. She also couldn't tell me if they IQ test at the school, she said she was a new principal.

FD: We keep hearing that America is obsessed by testing, is this part of that test obsession? Is it true you are test obsessed? 
EK: Yes, but when you say "America" it doesn't describe what is going on because we have many divisions in this country between those who are pushing the testing and standardization movement and those who want less federal level control and more local control over education.

Many educators here believe that testing is being driven by testing companies like Pearson, who then make billions of dollars from the international market for textbooks, tests and online classes. In this view, we are living in the era of the Global Educational Reform Movement, un-lovingly characterized as GERM, a term popularized by Pasi Sahlberg (Sahlberg 2012). This view directs us to a central contradiction in education today.

The GERM view postulates that there are global educational design that should shape global education practices. Examples of the hegemonic nature of this movement include, international test score comparisons, online teacher preparation programs with a worldwide reach, and education textbook companies that propagate a global message about 'best teaching practices.' In this neoliberal view, there is nothing local only global.

There are policy elites in this country who believe that national standards and national testing will help us overcome the academic achievement gaps in this country. (Ncsl.org 2016). They also argue that without testing our students, we will never compete in the global economy. In this view, schooling prepares the young to compete globally for jobs; global educational systems can prepare teachers to teach anywhere, with a global ideology that underlies that training. 
Then there are parents who say, "My kids are stressed out because all they do is tests" and teachers who say they spend all their time giving benchmark tests and teaching to the test. Some parents have withdrawn their kids from the testing regimes altogether and those who can afford it send their kids to private schools which are not required to test in the same ways that public schools do. Many principals are opposed to the testing because it kills teachers' creativity and it's how we rank schools. No one rooted in classroom life thinks testing is an accurate or full measure of anything really. And now teachers are being evaluated based on their students' test scores, but the tests were never designed to evaluate teachers. But of course, high test scores on international tests is what put Finland in the educational spotlight.

FD: There's this idea that testing is non-existent in Finland, I've met so many people who are like, "Oh my god you're not testing in the schools, the kids are free of tests, etc." Testing happens all the time in Finland, but not as much at the national level. The new National Curriculum Framework in Finland suggests using different kinds of assessment such as peer or self-assessment. Can I ask you who determines testing in the US, is it at the state level or even district level?

EK: Testing is driven by the federal level and the state level. We have the National Assessment of Education Progress given nationally and results are compared across the nation. Then states have their own assessments, Arizona is in transition to a new assessment to be used next year. Added to these tests, is the dozens maybe hundreds of benchmark tests that occur all the time in classrooms. So, decisions about which tests are 
going to be given in the state is a decision at the state level. This may change next year when we re-authorize the federal legislation that controls the relationship between the federal government and local schools. States are clamoring for more control over which tests they use and over national standards.

ALR: There are national tests in Finnish basic education, but they are voluntary so the teachers can decide. Not all teachers, but probably many of them, administer the tests and then they can see at the national level how they are doing.

FD: The final matriculation examination is so important for your future in Finland because it determines whether you enter the university. Students take it by the age of 18 and it creates hierarchies, even amongst teachers, "Oh, I have ten Laudaturs" (Laudatur is a top grade). I hear very often, people saying, "Oh, he's so clever he got ten Laudaturs" but that is not a sign of being clever really.

ALR: This is repeated later in life, when people say, "Well, actually, I graduated from high school with seven Laudaturs. Some people use that as status. So while Finland has been branded as the country without tests, we have this test and people carry the results all their life. And then grades determine what high schools you can go to, so students are ranked and sorted before they start high school and then again as they finish, and that exam determines whether you go to college or technical training or just start work.

EK: The last point that we have had lots of discussion about is the presence of LGBTQ clubs and posters on the walls of our schools. 
FD: I noticed the signs and posters and I would say it was a very nice surprise to see that this is put on the table. It is on the wall, you can see the label and people start reflecting on the fact that "oh it is acceptable" and to know there is a place where you can talk about it. That level of acceptance is unknown in Finland schools.

ALR: I was very pleased to see it because I haven't seen any sign of LGBTQ in Finnish schools. Maybe there is something in certain high schools that are very art oriented or elite schools and maybe it is part of that culture but, in general, it's not.

EK: The other thing that's happening here is the legal rights of transgender students. That's gone through a number of court cases around the country in different states trying to figure out what bathrooms do transgender students use, what showers do they use, and who determines that? This is a huge debate in schools here.

FD: We don't have these discussions in Finland, although they are trying to organize something related to queer education in my department. Remember that Finland was one of the last countries in Europe to allow same-sex marriage. Many people still feel uncomfortable about the LGBTQ community. And the level of interest is basically null in schools; nobody's interested to take part in the meetings to discuss how this could be implemented more systematically in teacher education for example. I've always said that Finland is, in a sense, and maybe I'm exaggerating, quite homophobic. In general, it's a very homophobic society.

ALR: There is this discussion among some in Finland, although not among elected officials, but there are groups of people who try to do something but it is still at the 
private level of discussions. There are some who are trying to make it a more public discussion because we need to talk about this issue because it exists. But there is not much happening in teacher education around these issues really yet, even if there have been some projects and initiatives on gender and sexual equality, but still many teacher educators can bypass these things and implicitly or explicitly support the heteronormative order (Lehtonen 2011). And the students I have discussed these things with usually say that it is the very first time such things are discussed in teacher preparation classes. We have some research projects (Lahelma 2014) bringing up gender and sexuality issues, but it is still very new and not part of the mainstream.

FD: This research work is not disseminated in a sense, so some people say "teachers are homophobic" but there's no further step. These projects don't go any further than to try to prevent that, they say we just need to train teachers. But here the schools seemed welcoming and accepting of these students because there is attention to them through clubs and assembly programs. Very different from what we see in Finland.

EK: These surprises that you experienced in our schools has given me a new way of seeing our schools, so I thank you for that. But one of the things that creates dissonance for me, and others who have heard you speak while you have been here is that you critique the official, branded narrative coming out of Finland. Finland has a huge education industry, you export Angry Birds Playgrounds to Singapore and China, set up schools like the Qatar Finland international school (http://qatarfinlandschool.com) in Doha and charge educators thousands of dollars to visit your schools and Departments of teacher education. Finland 
has also created, amongst others, Future Learning Finland, which organizes the educational export economy of Finland and appointed a Chief Specialist ('Ambassador') in Finnish Education Export. But what would others who talk internationally about the miracle of Finnish education say about these issues we are talking about here? You both are so critical of what's going on in Finnish schools and that criticism doesn't come from other Finns who are here.

FD: First of all, many of these loud voices about the Finnish miracle haven't been in a classroom for years. These are Finns who live internationally in Italy, Washington, and other parts of the US and occasionally Finland. I think that their vision of Finnish education is very limited and exaggerated to please their audience and make themselves exotic and different. They say that we don't have discipline problems, that there is no homework, no assessment/evaluation, that all our teachers are very good and respected, that we don't have private schools, etc. (see Dervin 2016). They rely on and write the official narrative that gets out, often contributing to the education export industry and/or boosting their own fame. But these are 'white lies', and I would even go as far as asserting that this is propaganda created by the market (Liu and Dervin 2016). It is very similar to selling an iPhone: they only sing the praises of Finnish education and silence the real big problems. Some days ago a video emerged in Finland showing a teacher losing it because her students were rude, disrespectful and disruptive (see https://www.youtube.com/watch?v=R6o4OxG0nPY). The video was shot by students. The teacher was fired afterwards. Are teachers really as well respected as they say? In an article that I co-wrote with Punakallio (2015) we showed that the image of the teacher 
has changed drastically in the Finnish press over the last 10 years and that the idea that teachers are "candles of the nation" is seriously being questioned. So yes this is also part of the Finnish educational landscape. It is not Disneyland. In a chapter I wrote about this I used the metaphor of the "Emperor is naked" to describe the realities of Finnish education (Dervin 2016). Probably if the promoters of Finnish education heard what we were saying they'd say we're lying or we don't know what we're talking about, we don't have the facts generated by international organizations like the Organization for Economic Cooperation and Development (OECD) and we don't have all of those figures. But we are on the ground in the schools in Finland, doing research on social justice and training the teachers and we know the reality of schools today in Finland (see e.g. Layne and Dervin 2016).

ALR: They might think what we're talking about is a minimal issue. But issues of student and teacher identity are very important right now in Finland, not to mention the so-called migrant crisis that will rapidly change what goes on in schools. So we are in transition, yet these voices about the Finnish miracle are talking maybe about the past.

FD: One very loud voice is Pasi Sahlberg. I think that he is very contradictory because he's critical of international tests like PISA, but every time he wants to prove a fact to show that Finland is doing miracles, he will use data from the OECD. There's this sort of chameleon perspective. If you read him in Finnish and English he can be saying totally different things and very contradictory perspectives and I think that it's created this aura around him. He came at the right time, when these rankings have become so important, 
people are dissatisfied with the politics, the economy's going down, etc. He came to be a savior in a sense, I'm going to show you how we do it in Finland. He claims that he doesn't want to tell people that Finland is great or he doesn't want to give advice to other countries. But every time he puts his presentations online it's all about this. It's all about that's what you should do. And a lot of these sources... really there is a lot of exaggeration and propaganda.

But since we are talking about the branded nature of the Finnish education miracle, that narrative must have shaped your interest in coming to visit our schools. But what about our schools, were there things that surprised you?

EK: I was very interested when I was in Jyväskylä, there were a series of posters about creating a $21^{\text {st }}$ century school. My tour guide said that the students did a design for a new school building and that the students were actually involved with the architects. It surprised me because the schools in Finland didn't seem particularly student-centered.

FD: I don't know about that project but would ask how much of that activity was related to the justice, the inclusion of people in decision-making? Is that a simple exercise where we are going to design a nice place? How much of that discussion was related to the actual power of the kids? The new National Curriculum Framework insists on negotiation with kids to design learning spaces but I am not convinced that this is happening... not all kids have the same power in Finland... As Anna-Leena hinted at earlier, so-called migrants and refugees from certain parts of the world can be too easily excluded from deciding upon things in Finnish schools... 
EK: I didn't see anything on the walls that was celebrating diversity or celebrating difference. But the migrant crisis was just beginning. There was a lot of student art work up so it seemed that it was very student centered in that way. I didn't see anything political really, especially in terms of sharing power with students.

ALR: We don't really let political messages get posted in our schools, or educational institutions. In our university building we put up stickers and also posters on the corridors saying, "Refugees welcome, no one is illegal". In a three week period, someone removed them six or seven times. and we always put up new posters again and again. Somebody at the department doesn't really like putting political messages in our walls.

EK: I guess what didn't surprise me, but has resonated with me is that I think there is a secret sauce in Finland and it is the 15-minute recess every hour and the fresh food in the cafeterias. The level of calm in the schools and the clean and well-organized school environments and classrooms were a pleasure to be in really.

There is also the role of reflection in the schools in Finland that really impressed me. One first grade teacher showed me the cards she used with her students for parent conferences. The students gave an assessment of their own learning in all the subject areas they were studying and that reflection was the basis of the parent teacher conferences. I was told that happens all the way through school. I sat in on student teacher discussions with their mentor teacher, when the mentor teacher would ask the student teacher how they thought their lesson went, I was amazed frankly, at the level of reflection and self-assessment on the part of the student teachers. I think that early training in reflection helps new teachers learn to 
teach. I also wonder if it doesn't lead to the interest in Finland in teaching because you are engaging students in their education early on.

FD: The recess might make a difference here, I don't know, but it's only one thing in the huge ocean of educational challenges. But in a sense I'm very glad there were things that you noticed in the Finnish schools that you visited that you'd like to see implemented here. Yet, I see them as details compared to the rest and all the hype around how wonderful the teachers are, how progressive we are in terms of how we're teaching things and the use of technology. I presented the new National Curriculum Framework at an international conference recently. People were expecting 'miraculous ideas' (that's how it is being sold globally) but the audience laughed when I presented the core ideas (autonomous learning, student-centeredness, multidisciplinarity, cultural diversity, etc.). These are actually old ideas that have been relabeled in a 'Finnish sauce' as you would say, Etta. But you have said you were not too impressed by the technological aspects of teaching or even the pedagogical approaches in the classrooms you visited.

EK: The pedagogical practices that I saw were very traditional in the sense that it was still a teacher centered classroom, the students were still marching through pages of textbooks, even though the pages were projected on a screen in front of the class and there was a voice reading the text and the teacher sat at her desk watching the class. Of course this wasn't every class, but there was a lot of that kind of technology in the classrooms. 
FD: We have talked a lot about this, why don't we like teacher centeredness? Why suddenly is everyone obsessed with student centeredness? I see student centeredness as a little bit neo-liberal, we do it a lot in Finland but in many cases it is a way of delegating the work to the students without always training them to do it - and save time and money from teaching. If you are going to assess yourself, you're going to determine what you learn. That's so unfair because if you've got support from home maybe it's easier for you to determine what you want to learn. If you get no support, maybe you will be happy with just the tiny bit of learning. Do you know what I mean? I'm so tired of this student-centered thing. We all went through teacher centered and we're not stupid, we are critical.

ALR: I think that student centered is a lie itself from the very beginning. I think school aims to make citizens and train a workforce with a global reach. And that's not student centered, it's student centered only if the students are not told, 'go where you need to go.'

EK: I think we could clarify what we mean by student-centered, I think you mean something different by student-centered than I do.

Fred: I mean autonomous learning, placing the students at the center of our practices. Teachers abandoning some of their control. That's how it's usually presented in our context. How would you define student-centered?

EK: I am a progressive educator, so for me student-centered has a long history with roots in Rousseau, articulated by Dewey, and practiced by progressive schools where students engage in project-based learning and inquiry. I would define student-centered as educational practices where the students are designing research projects, where the students 
are asking the questions that they care about and then doing the research to answer those questions. These schools are communities in the Deweyan sense of the word. It is really hard to be student-centered in an age of GERM, but there are many progressive schools in this country that try to move beyond thinking of education as being in service to the state and the economy. We had a progressive high school in Southern California where we went camping for three days to design the curriculum for the year. I taught for years at College of Atlantic, which offers one degree in Human Ecology where students construct their academic program in collaboration with a faculty advisor. So my experience with progressive education has taught me that when students are the architects of their own education, amazing things happen. That kind of freedom in education is central if education is to serve the student rather than the state.

FD: I don't see it as possible to move education outside an ideological framework that shapes the curriculum. For example, Precious Knowledge, the film we watched about the Mexican American studies programs in Tucson; I'm sorry, but I didn't see much criticism from the side of the students about what they were being taught. They were critical about aspects of their lives, but I didn't see any criticality towards what the teachers were saying. They seem to be swallowing all of it as if it were the Bible, hence this sort of religious feeling that I had when I saw some of it happening. Do you know what I mean?

ALR: I know what you mean, I felt the same way about the lack of criticality toward the Mexican American studies curriculum. 
EK: It's funny you say that because I have students who were graduates of those programs in Tucson, and they are very critical of what the curriculum is in our teacher education program. I also think that a sense of belonging is really important for high school students and for many of the students in those programs, their sense of belonging came from those classes, just like for other kids their sense of belonging in high school might be through music programs or sports programs. Also, I think that by the time they made the documentary, Precious Knowledge, Mexican American studies was under attack, so part of the point of that film was to defend it. The whole educational movement was basically outlawed while they were making the film. There might have been more a defensive dogmatic approach at the end of the film than there was earlier; I don't know if that's true or not. You could ask.

FK: I worry a little bit about this sort of approach because I like it, but I'm also worried that it's like indoctrination. You start believing in the ideas that were passed onto you without being critical or reflexive towards them. I think that is as dangerous as doing nothing.

EK: I guess that raises the question that Anna-Leena has been asking, "is it possible to have education without indoctrination?" Maybe today because of standards and testing that do in fact carry the ideological framework of the GERM movement, education and indoctrination have become more fully knitted together. But there is a long tradition of progressive education in this country where that is not the case and progressive schools 
today are trying to push the edge while being true to their progressive philosophy, maybe you would call that ideology too.

ALR: I would problematize even that. From my point of view, if education is made to serve certain kinds of structures, then indoctrination is always there. Schooling and institutionalized educational system function to maintain and reproduce the society including the unfair social order, so we don't have an escape from indoctrination (Durkheim 1956). We have some space to move inside the system, but we can't escape the direction education is moving in terms of the embrace of a global system.

FD: To me we're all going in a certain direction and there was no questioning of the direction in the schools and classrooms either in this country or Finland. There's a responsibility for us to push criticality into all corners of the educational experience and not to be selectively critical. To be critical over everything is necessary because everything is ideological and it's challenging ideology that becomes key in this age. That is why I am very critical of the narratives that people in the U.S. are fed in relation to Finnish education. There is no paradise on this planet. We are all good and bad.

EK: On that gloomy note, our time is up, is there anything else either of you would like to add?

FD: Yes, the schools we saw were communities. The teachers were caring toward their students, you could tell that most respected the students and were respected by them. That is very impressive. To us, the LGBTQ groups in the schools demonstrate the essence of a student-centered school, or maybe we should call it progressive, where students are 
allowed to be themselves and they are accepted. I am not deluded into thinking that this happens in all schools in this country, and maybe the rural nature of this place can account for some of the community feeling in the schools or maybe it's because you have all these extra-curricular activities that we typically don't have in Finland. But it was very impressive and the schools we visited felt good to be in.

\section{Final thoughts}

This visit has inspired an ongoing collaboration on projects related to comparative studies of our schools. We have gone on to begin editing a book on education on the border and two papers on school environments have been published. (Riitaoja et al. 2009; Orozco 2016) Fred will return to the border next year to do follow up visits at the schools and to give public talks.

Our time together in border schools helped me understand the value of an honest dialogue across differences. It has also allowed all of us to become even more aware of the fact that, "we are each other's figment of the imagination" (Finland/USA, Dabashi and Mignolo 2015, 30).

There were many folks who heard Fred and Anna-Leena speak and were surprised that they were so critical of Finnish schools. Certainly the distance between how they characterized Finnish schools and the official narrative about Finnish education caused varying degrees of discomfort in our audiences. No doubt the intense media coverage that Finland has gotten in the past 10 years has helped shape and spread the narrative about 
education in Finland, but not everyone in Finland sees the same educational landscape created by Sahlberg and CNN (Sahlberg 2014; Dervin 2016).

As I write this, it will have been close to a year since Fred and Anna-Leena were here. In that time the landscape for the above discussion has changed a bit. The issue of the flag salute in schools is coming into play in the controversy over professional athletes kneeling during the national anthem to protest police brutality and racial inequalities in our society. Now, students in high schools are beginning to join in the movement. This form of protest has not spread to the schools we visited, yet. And if it does, it will be interesting to see how the protesting students treat saluting the flag each day. I suspect for many of us, the flag salute in school is one of those invisible practices that we accept uncritically and do unthinkingly. Yet, according to WNPR's David DesRoches, the US is the only industrialized country where students salute the flag in school, even though it has been unconstitutional to force students to recite the pledge since 1943. (DesRoches, 2015)

Our discussion about the meaning of the flag salute and the blurry boundary between patriotism and nationalism, sidestepped the issue of the demands democracy places on its schools (Dewey 1915). Central among them is the need for the school to be a model democratic community so young citizens will come to value democracy. When Fred talked about the schools as communities it struck me that while we might have achieved that somewhat; our larger political fracas convinces me that many of us live in an echo-chamber vortex that keep us from community. And in some ways, schools are the places where these 
conflicting vortices collide, most notably around the cultural issues that divide this country. The demands a democracy places on its schools are more crucial now than ever, and perhaps more illusive in the age of GERM.

Our Finnish visitors left before the Obama administration's announcement in 2016 that schools had to allow transgender students the right to use school bathrooms and locker rooms of their choice. Since then our schools have been scrambling to come to grips with what this mandate means in schools with old style gang shower rooms, which are the norm in most high schools in rural Arizona. This mandate has provoked significant litigation.

During this same time, Finland has recently adopted a new National Curriculum Framework (NCF). This framework calls for an extended period for multidisciplinary, phenomenon-based teaching and learning. Pasi Sahlberg posts:

"What Finnish youth need more than before are more integrated knowledge and skills about real world issues, many argue. An integrated approach, based on lessons from some schools with longer experience of that, enhances teacher collaboration in schools and makes learning more meaningful to students" (Sahlberg 2015).

Sahlberg also reminds us that in Finland there is strong local control that lets schools and teachers respond to local conditions, so the reforms will look very different in different schools. This, of course, can lead to differential treatment and missed opportunities in some schools that can't afford 'full' innovation. According to the Minister of Education 
in Finland, the changes are driven in part by research findings that one quarter of students in Finland don't like school and feel they don't belong. (Will 2016).

Perhaps this is one reason why Fred wanted to be sure to add that he thought our schools were communities and that students felt respected and included. At least to Finnish eyes, there are a few such schools on the Arizona/Mexico border. I was sure that they would see the same broken down school buildings, burned out teachers and pockets of brilliance that characterize many public schools on the border. Instead they saw small schools where teachers and students were actively engaged in the work of teaching and learning, funny the test scores don't reflect that.

\section{References}

Billig, Michael. 1995. Banal Nationalism. Thousand Oaks, CA: Sage

Cavanaugh, William T. 2004. "Killing for the Telephone Company: Why the NationState is Not the Keeper of the Common Good." Modern Theology 20 (2): 243-274.

Dabashi, Hamid, and Walter Mignolo. 2015. Can non-Europeans think?. London: Zed Books.

Dervin, Fred. 2016. "Is The Emperor Naked? Experiencing the 'PISA hysteria', branding and education export in Finnish academia." In: Trimmer, K (Ed.). Political Pressures on Educational and Social Research. London: Routledge: 77-93.

Dewey, John. 1916. Democracy and Education. New York: Macmillian Press.

DesRoches, David. 2015. "Do Schools in other Countries Recite a Pledge of Allegiance?” On Course Blog. Accessed November 142016. http://ctoncourse.org/post/126591697292/do-schools-in-other-countries-recite-a-pledgeof.

Durkheim, Emile. 1956. Education and Sociology. New York: The Free Press. 
Holliday, Adrian. 2010. Intercultural Communication and Ideology. London: Sage.

Hökkä, Päivi, and Anneli Eteläpelto. 2014. "Seeking new perspectives on the development of teacher education a study of the Finnish context." Journal of Teacher Education 65 (1): 39-52.

Husu, Jukka. 2003. "Constructing ethical representations from the teacher's pedagogical practice: A case of prolonged reflection." Interchange 34 (1): 1-21.

Jääskeläinen, L., Hautakorpi, J., Onwen-Huma, H., Niittymäki, H., Pirttijärvi, A., Lempinen, M. \& Kajander, V. (2016). Tasa-arvotyö on taitolaji: Opas sukupuolen tasaarvon edistämiseen perusopetuksessa [Skills of equality work: Guide for propoting gender equality in comprehensive education]. Helsinki: National Board of Education.

Klaus, Karl. 1990. In These Great Times. Amsterdam: November Editions.

Kowalczyk, Jamie, and Thomas S. Popkewitz. 2005. "Multiculturalism, recognition and abjection:(Re) mapping Italian identity." Policy Futures in Education 3 (4): 423-435.

Lahelma, E. (2014). Troubling discourses on gender and education. Educational Research, 56(2), 171-183, DOI: 10.1080/00131881.2014.898913

Layne, Heidi, and Fred Dervin. 2016. "Problematizing Finland's pursuit of intercultural (kindergarten) teacher education." Multicultural Education Review 8 (2): 1-17.

Lehtonen, J. (2011). Sukupuolitietoisuuden lisääminen opettajankoulutuksessa ja oppilaitoksissa opetushallinnon ja projektien tavoitteena [Increasing gender awareness in teacher education and educational institutions as an objective of educational administration and project work]. In Brunila, K., Heikkilä, M., Hynninen, P., JakkuSihvonen, R., Lahelma, E., Sunnari, V., Virkkunen, H. \& Lehtonen, J. (Eds). Sukupuolinäkökulmia tutkimusperustaiseen opettajankoulutukseen [Gender perspectives to research-based teacher education] (pp. 9-33). Helsinki: University of Helsinki.

Liu, Haiqin, and Fred Dervin. 2016. "Education is a life marathon rather than a hundredmeter race": Chinese 'folk' comparative discourses on Finnish education." Compare: A Journal of Comparative and International Education. (need page numbers)

López López. Ligia Licho. 2006. Language, science, and a mission: another look at pluralism. Knowledge Cultures 4 (2): 55-72.

Maaranen, Katriina, Heikki Kynäslahti, and Leena Krokfors. 2008. "Learning a teacher's work." Journal of Workplace Learning 20 (2): 133-145. 
Niemi, Hannele, Auli Toom, and Arto Kallioniemi. 2012. Miracle of Education: The Principles and Practices of Teaching and Learning in Finnish Schools. Sense Publishers.

"No Time to Lose: How To Build A World-Class Education System State By State." 2016. Ncsl.Org. Accessed November 142016.

http://www.ncsl.org/research/education/no-time-to-lose-how-to-build-a-world-classeducation-system-state-by-state.aspx.

Orozco, Richard. 2016. (in press) Poblano High School: Signifying the possibilities of silent partners. In T.Itkonen, \& F. Dervin (Eds.), Silent Partners in Education. Charlotte, NC: Information Age Publishing.

Partanen, Anu. 2011. "What Americans keep ignoring about Finland's school success." The Atlantic. Accessed November 142016.

http://www.theatlantic.com/national/archive/2011/12/what-americans-keep-ignoringabout-finlands-school-success/250564/.

Phippen, J. 2015. "How Teachers Started Smuggling Books To Save Ethnic Studies". The Atlantic. Accessed November 172016.

http://www.theatlantic.com/education/archive/2015/07/how-one-law-banning-ethnicstudies-led-to-rise/398885/.

Punakallio, Ella, and Fred Dervin. 2015. "The best and most respected teachers in the world? Counternarratives about the 'Finnish miracle of education' in the press." Power and Education 7 (3): 306-321.

Riitaoja, Anna-Leena, Heidi Layne, Haiqin Liu, Heini Paavola, Etta Kralovec, and Richard Orozco. 2015. "Constructing Norms and Silences on Diversities Through the Spaces in Three Schools in Helsinki Region in Finland." World Studies in Education 16 (2): 19-32.

Sahlberg, Pasi. 2012. "How GERM is infecting schools around the world." The Washington Post, June 29.

Sahlberg, Pasi. 2014. "Why Finland's Schools Are Top-Notch." CNN, October 6. Accessed November 14 2016. http://www.cnn.com/2014/10/06/opinion/sahlberg-finlandeducation/.

Sahlberg, Pasi. 2015. "Finland's school reforms won't scrap subjects altogether." The Conversation, 25.

Somers, Margaret R., and Olin Wright. 2008. "Genealogies of citizenship: Markets, statelessness, and the right to have rights." Cambridge: Cambridge University Press. 
Will, Madeline. 2016. "Finland's Education Minister Discusses New National Curriculum and PISA Scores". Education Week - Curriculum Matters. Accessed November 142016. http://blogs.edweek.org/edweek/curriculum/2016/10/finland_education_minister.html. 